\title{
Percutaneous Dilatational Tracheostomy (PDT) Dini Sebagai Upaya untuk Mencegah Pneumonia dan Mempermudah Perawatan Pasien Stroke di Intensive Care Unit (ICU)
}

\section{Early Percutaneous Dilatational Tracheostomy as an Effort to Prevent Pneumonia and Facilitate Treatment of Stroke Patient in Intensive Care Unit (ICU)}

\author{
I Wayan Suryajaya ${ }^{\text {冈* }}$, Prananda Surya Airlangga ${ }^{* *}$, Eddy Rahardjo** \\ *Departemen Anestesi dan Terapi Intensif, Rumah Sakit Angkatan Laut Dr. Ramelan Surabaya, \\ Indonesia \\ ** Departemen Anestesiologi dan Terapi Intensif, Fakultas Kedokteran, Universitas Airlangga/ \\ RSUD Dr. Soetomo, Surabaya, Indonesia
}

${ }^{\circledR}$ Korespondensi: wayan_anest@yahoo.com

\begin{abstract}
Background: Stroke or cerebrovasular accident (CVA) is a rapidly loss of brain functions due to disruption of blood supply in to the brain. It is not uncommon for stroke patients to be treated in the intensive care unit (ICU) because they experience respiratory failure that requires a ventilator. The inadequate ability to swallow and cough reflexes in stroke patients often cause complications of pneumonia/ stroke associated pneumonia (SAP). Complications of pneumonia can also be caused by the usage of ventilators which are often called ventilator associated pneumonia (VAP). SAP and VAP in stroke patients can be prevented by early tracheostomy. Percutaneous dilatational tracheostomy (PDT) is a tracheostomy technique by making a minimal incision to insert the guide wire as a guide. Then the tracheostomy hole is widened using multiple dilators until the canule tracheostomy can fit in the trachea. PDT is easier to do than surgical tracheostomy, so it is more beneficial for critical patients in the ICU.

Case: There are 3 cases of stroke patients reported with glasgow coma scale (GCS) below 8. First case: Stroke patients with subacute infarct in the basal ganglia dextra and cerebral edema. GCS E1V2M1 The patient has a partial airway obstruction. The patient was treated in the ICU and underwent intubation. PDT is done on day 2 with the aim to secure the airway and facilitate bronchial toilet so that it can prevent pneumonia.

Second case: Stroke patient with extensive infarction in the right hemisphere. The patient was treated in the ICU with a ventilator. PDT is done on day 8 to facilitate breathing physiotherapy, bronchial/ tracheal toilet. After 50 days the patient was transferred to the room without pneumonia.

Third case: Patients with decreased awareness of GCS E2V1M3. The patient was treated in the ICU with partial airway obstruction. PDT is done on the first day with the aim of keeping the airway safe and facilitating the tracheall bronchial toilet. The patient was treated for 110 days and moved to the room.
\end{abstract}


Discussion: In all three cases an early attempt at tracheostomy/ PDT was aimed for securing the airway to remain free, facilitating oral hygiene and performing physiotherapy in the form of tracheal/ bronchial toilet. Tracheostomy also facilitates the mobilization of patients so that it is an effort to prevent pneumonia during treatment. During the treatment of these patients in the ICU pneumonia complications do not occur until the patient is out of the ICU.

Conclusion: Stroke patients with GCS below 8 will experience long-standing care and the potential for complications in the form of SAP and VAP when using a ventilator. Early tracheostomy in addition to simplifying treatment and accelerating weaning is also an effort to prevent pneumonia. PDT is a suitable tracheostomy technique for critical patients in the ICU because it is more beneficial than surgical tracheostomy.

Keywords: percutaneus dilatational tracheostomy; PDT; pneumonia; SAP; stroke

\begin{abstract}
ABSTRAK
Latar Belakang: Stroke atau cerebrovasuler accident (CVA) merupakan hilangnya fungsi-fungsi otak dengan cepat akibat terganggunya suplai darah ke otak. Tidak jarang pasien stroke dirawat di intensive care unit (ICU) karena mengalami gagal napas sehingga membutuhkan ventilator. Kemampuan menelan dan refleks batuk yang tidak adekuat pada pasien stroke sering menyebabkan komplikasi pneumonia/ stroke associated pneumonia (SAP). Komplikasi pneumonia bisa juga disebabkan oleh penggunaan ventilator yang sering disebut ventilator associated pneumonia (VAP). SAP maupun VAP pada pasien stroke dapat dicegah dengan tindakan trakeostomi dini. Percutaneous dilatational tracheostomy (PDT) merupakan teknik trakeostomi dengan melakukan sayatan minimal untuk memasukkan guide wire sebagai panduan. Kemudian lubang trakeostomi diperlebar dengan menggunakan multipel dilator sampai canule trakeostomi bisa masuk ke trakea. PDT lebih mudah dilakukan dibanding surgical tracheostomi sehingga lebih menguntungkan dikerjakan untuk pasien kritis di ICU.
\end{abstract}

Kasus: Terdapat 3 kasus pasien stroke yang dilaporkan dengan glasgow coma scale (GCS) dibawah 8. Kasus pertama: Pasien stroke dengan subakut infark di basal ganglia dekstra dan oedema cerebri. GCS E1V2M1 Pasien mengalami sumbatan partial jalan napas. Pasien dirawat di ICU dan diakukan intubasi. PDT dikerjakan hari ke 2 dengan tujuan untuk mengamankan jalan napas dan mempermudah bronchial toilet sehingga dapat mencegah terjadinya pneumonia.

Kasus kedua: pasien stroke dengan infark luas di hemisphere kanan. Pasien dirawat di ICU dengan ventilator. PDT dilakukan pada hari ke 8 untuk mempermudah melakukan fisioterapi napas, bronkial/trakeal toilet. Setelah 50 hari pasien dipindahkan ke ruangan tanpa ditemukan pneumonia.

Kasus ketiga: Pasien dengan kesadaran menurun GCS E2V1M3. Pasien dirawat di ICU dengan sumbatan partial jalan napas. PDT dilakukan pada hari pertama dengan tujuan mempertahankan jalan napas tetap aman dan mempermudah tracheal/ bronchial toilet. Pasien dirawat selama 110 hari dan pindah ke ruangan.

Pembahasan: Pada ketiga kasus tersebut dilakukan usaha tracheostomi/ PDT secara dini dengan tujuan mengamankan jalan napas tetap bebas, memudahkan oral hygiene dan melakukan fisioterapi napas berupa tracheal/ bronchial toilet. Trakeostomi juga memudahkan mobilisasi pasien sehingga merupakan upaya untuk mencegah terjadinya 
pneumonia selama perawatan. Selama perawatan pasien tersebut di ICU tidak terjadi komplikasi pneumonia sampai pasien keluar dari ICU.

Kesimpulan: Pasien stroke dengan GCS dibawah 8 akan mengalami perawatan yang lama dan potensial terjadi komplikasi berupa SAP maupun VAP bila memakai ventilator. Trakeostomi dini selain mempermudah perawatan dan mempercepat weaning juga sebagai upaya untuk mencegah terjadinya pneumonia. PDT merupakan teknik trakeostomi yang cocok dilakukan untuk pasien kritis di ICU karena lebih menguntungkan dibanding surgical tracheostomy.

Kata Kunci: percutaneus dilatational tracheostomy; PDT; pneumonia; SAP; stroke

\section{PENDAHULUAN}

Stroke atau cerebrovasuler accident (CVA) merupakan hilangnya fungsifungsi otak dengan cepat akibat terganggunya suplai darah ke otak. Stroke ada dua tipe utama yaitu iskemik akibat berkurangnya aliran darah sehubungan dengan penyumbatan (thrombosis, emboli), dan hemorrhagic akibat perdarahan. ${ }^{1}$

Di Indonesia kejadian stroke sekitar 12 dari 1000 orang dan 1 orang dari 7 pasien meninggal dunia. ${ }^{2}$ Stroke memerlukan penanganan medis yang akurat untuk mencegah kerusakan otak lebih parah. Stroke merupakan penyebab kematian terbesar ketiga di Eropa dan Amerika Serikat. Selain itu stroke juga menyebabkan angka kecacatan terbesar di dunia. ${ }^{2}$

Beberapa pasien stroke akan dirawat di ruang intensif seperti di stroke unit maupun di ruang intensive care unit (ICU). Tidak jarang perawatan pasien stroke di ICU memerlukan perhatian dan alat-alat canggih seperti ventilator, monitor untuk hemodinamik, alat untuk menguasai jalan napas dan sebagainya. Pasien stroke yang disertai dengan gagal napas akan membutuhkan ventilator untuk menjamin ventilasi yang adekuat. Permasalahan yang sering muncul setelah pasien dipasang ventilator adalah kesulitan untuk weaning sehingga membutuhkan alat bantu napas dalam waktu lama. Penggunaan ventilator yang lama akan memunculkan masalah baru berupa infeksi pada paru yang lazim disebut ventilator associated pneumonia (VAP), bahkan sebelum dipasang ventilator pasien stroke sering mengalami pneumonia yang disebut strokes assosiated pneumonia (SAP). ${ }^{3,4}$

Pneumonia merupakan komplikasi yang sering terjadi pada pasien stroke sehingga menyebabkan angka kematian meningkat. Pada pasien stroke akan mengalami gangguan menelan, refleks batuk yang tidak adekuat, oral hygiene yang tidak baik sehingga akan memperbesar terjadinya komplikasi SAP. ${ }^{5}$

Prognosis pasien stroke yang memakai ventilator di ICU sangat buruk dengan angka kematian 40-80\%. Optimalisasi penanganan jalan napas akan membantu untuk memperbaiki outcome serta dapat mencegah terjadinya aspirasi dan pneumonia pada pasien stroke. ${ }^{5}$

Penatalaksanaan jalan napas di ICU dapat dilakukan dengan trakeostomi terutama pada pasien yang memakai ventilator dalam waktu lama dan susah di 
weaning. Waktu yang tepat untuk melakukan trakeostomi belum diketahui secara pasti. Beberapa penelitian menyebutkan waktu optimal melakukan trakeostomi 2-3 minggu setelah intubasi atau setelah terjadi kegagalan ekstubasi. ${ }^{6,7}$ Sebelum tahun 2005 ada 5 penelitian yang menyebutkan trakeostomi dini dilakukan 0-7 hari setelah pasien masuk rumah sakit akan memberikan keuntungan untuk menurunkan angka kejadian pneumonia/ SAP. ${ }^{5}$

Trakeostomi mempunyai keuntungan dalam perawatan pasien di ICU terutama pasien yang menggunakan ventilator lama dan susah disapih. Namun melakukan tindakan trakeostomi juga ada risikonya seperti: perdarahan, pneumothorak, emphysema subkutan bahkan trauma pada esophagus. $^{7}$

Sejak tahun 1985 teknik percutaneous dilatational tracheostomy (PDT) mulai berkembang dan semakin popular sebagai alternatif melakukan trakeostomi disamping teknik pembedahan. Sejak tahun 1990 PDT juga sudah berkembang di Eropa, Amerika serikat dan terus berkembang ke seluruh dunia. PDT merupakan prosedur trakeostomi dengan sayatan minimal yang bisa dilakukan pada pasien tirah baring di ICU. Banyak penelitian yang menunjukkan keuntungan PDT dibanding surgical tracheostomy meliputi komplikasi lebih rendah, risiko infeksi dan perdarahan lebih kecil, prosedur lebih cepat, dapat dilakukan di ICU sehingga tidak perlu transportasi ke ruang operasi. ${ }^{9-11}$

\section{KASUS}

Kasus 1

Wanita 55 tahun, berat badan $60 \mathrm{~kg}$ mengalami penurunan kesadaran sejak 3 hari. Pasien mengalami sumbatan partial jalan napas, frekuensi napas 24-26 $\mathrm{x} / \mathrm{menit}$. Perfusi hangat, tekanan darah 165/ $100 \mathrm{mmHg}$, nadi $112 \mathrm{X} / \mathrm{menit}$, GCS E1V2M1. Gambaran CT Scan: sub akut infark di basal ganglia dekstra dan oedema cerebri. Foto thoraks dalam batas normal. Hasil laboratorium: $\mathrm{Hb}$ $15,3 \mathrm{~g} / \mathrm{dl}$, leukosit 9,94, platelet 311.000, BUN/SC 22,2 / 1,5, albumin 3,4, GDA 465, Na / K 119 /2,8. Pasien dirawat di ICU kemudian dilakukan intubasi dan dipasang ventilator karena pasien mengalami gangguan pernapasan serta kecenderungan tidak dapat mempertahankan jalan napas tetap aman. Hari kedua dilakukan PDT oleh intensivist. Perawatan selanjutnya dilakukan fisioterapi napas secara berkala, tracheal/ bronchial toilet, suction, dan nebulizer untuk melembabkan udara pernapasan. Pasien ini juga diberi asupan nutrisi yang adekuat.

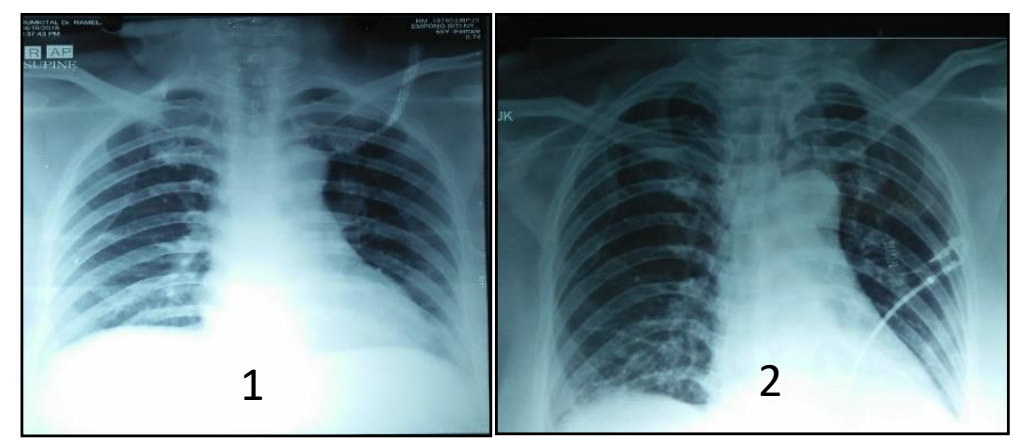

Gambar 1. Menunjukkan foto thoraks saat masuk ICU sebelum dilakukan trakeostomi tidak terdapat gambaran infiltrat. Gambar 2. Foto thoraks hari ke 30 pasca trakeostomi: paru bersih dan tidak terdapat gambaran infiltrat. 
Tenaga paramedis/ perawat di ICU berpendapat bahwa perawatan pasien dengan trakeostomi lebih mudah terutama saat melakukan mobilisasi dan suction. Pasien juga terhindar dari risiko endotracheal tube (ETT) terekstubasi. Pasien dirawat di ICU selama 35 hari tanpa timbul komplikasi pneumonia.

Tabel 1. Data pasien 1 selama perawatan

\begin{tabular}{llll}
\hline Kasus 1 & Sebelum Trakeostomi & $\begin{array}{l}\text { Hari ke } 1-7 \text { setelah } \\
\text { trakeostomi }\end{array}$ & $\begin{array}{l}\text { Hari ke 30 setelah } \\
\text { trakeostomi }\end{array}$ \\
\hline $\begin{array}{l}\text { Leukosit } \\
\text { Sekret }\end{array}$ & 9,940 & 7,060 & 6.560 \\
& $\begin{array}{l}\text { Sedikit, Putih, } \\
\text { tidak purulen }\end{array}$ & $\begin{array}{l}\text { Sedikit } \\
\text { tidak purulen }\end{array}$ & $\begin{array}{l}\text { Sedikit Putih encer } \\
\text { tidak purulent, }\end{array}$ \\
Suhu & $36,5-88.00$ & $36,7-37,5$ & $37-38$ \\
\hline
\end{tabular}

Kasus 2

Wanita 75 tahun, berat badan $50 \mathrm{~kg}$ datang ke instalasi gawat darurat (IGD) dengan stroke sejak 2 hari. CT Scan menunjukkan infark luas di hemisphere dekstra. Pasien mengalami sumbatan partial jalan napas disertai suara mendengkur, frekuensi napas 25 $\mathrm{X} /$ menit, $\mathrm{SpO} 2$ 95\% dengan oksigen masker sederhana 6 liter/menit. Perfusi hangat, tekanan darah 140/90 $\mathrm{mmHg}$, nadi $100 \mathrm{X} / \mathrm{menit}$, GCS E2V1M3. Hasil lab: $\mathrm{Hb} 12,4$, leukosit 16.270, platelet 296.000, SGOT /SGPT 31/29, BUN/SC $21 / 0,79, \mathrm{Na} / \mathrm{K} 139 / 3,8$.
Pada awalnya pasien dirawat di ICU dengan ventilator dan diintubasi ETT. Hari ke 8 dilakukan PDT oleh intensivist. Selama di ICU dilakukan fisioterapi napas, nebulizer, suction. Pasien juga mendapat terapi suportif nutrisi dan neurotropik. Weaning dimulai pada hari ke 10 dengan urutan mode ventilator CPAP, dilanjutkan $\mathrm{T}$ piece lalu masker trakeostomi.

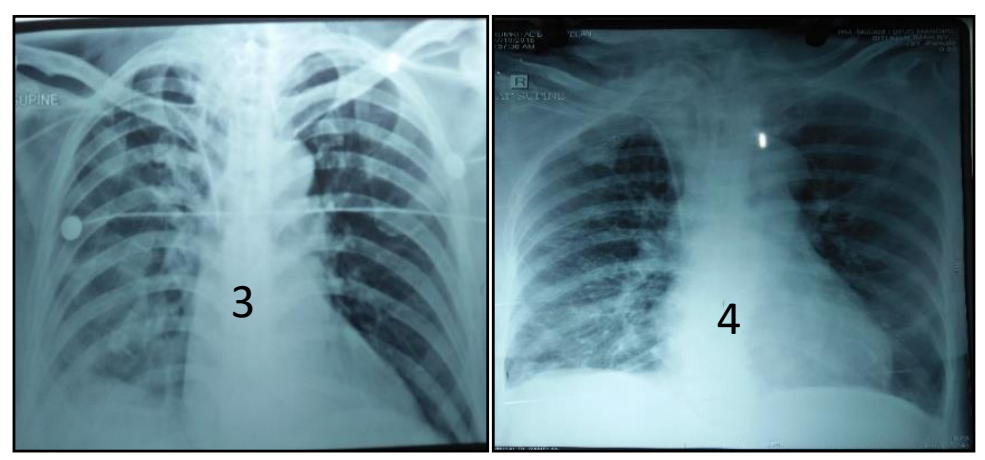

Gambar 3. Menunjukkan foto thoraks saat masuk ICU sebelum dilakukan trakeostomi tidak terdapat gambaran infiltrat. Gambar 4. Foto thoraks hari ke 46 pasca trakeostomi: paru bersih dan tidak terdapat gambaran infiltrat. 
Tabel 2. Data pasien 2 selama perawatan

\begin{tabular}{|c|c|c|c|}
\hline Kasus 2 & $\begin{array}{c}\text { Hari ke } 1 \text { setelah } \\
\text { trakeostomi }\end{array}$ & $\begin{array}{c}\text { Hari ke } 20 \text { setelah } \\
\text { trakeostomi }\end{array}$ & $\begin{array}{c}\text { Hari ke } 46 \text { setelah } \\
\text { trakeostomi }\end{array}$ \\
\hline Leukosit & 11.750 & 12.500 & 10.300 \\
\hline Sekret & Sedikit & Sedikit & Sedikit. \\
\hline & Tidak purulent & Tidak purulent & Tidak purulen \\
\hline Suhu & $36,5-37,8$ & $36,8-38,5$ & $36,5-38,5$ \\
\hline
\end{tabular}

Hasil tersebut dicapai setelah pemakaian antibiotik selama 5 hari selanjutnya pasien dirawat tanpa antibiotika sesuai petunjuk program pengendalian resistensi antibiotic (PPRA). Pasien dirawat di ICU selama 50 hari sebelum pindah ke ruangan.

Kasus 3

Wanita 80 tahun datang ke IGD dengan kesadaran menurun sejak 2 hari disertai dengan sesak napas, badan lemas, suara napas mendengkur. batuk lemah, dan demam. Pemeriksaan di IGD mendapatkan obstruksi parsial jalan napas, frekuensi napas 24X/menit, rhonki penuh seluruh lapangan paru. Tekanan darah 130/70 $\mathrm{mmHg}$, nadi 90x/menit teratur. GCS E2V1M3. Hasil lab: Hb. 12,6 g/dl, leukosit 11.750, platelet 273.000, BUN/SC 11,4/0,6, Na / K 110,2 / 3,11. Hari ke pertama di ICU dilakukan PDT oleh intensivist. Perawatan selanjutnya meliputi fisioterapi napas, tracheal/ bronchial toilet. Penyapihan ventilator dilakukan mulai hari ke 7.

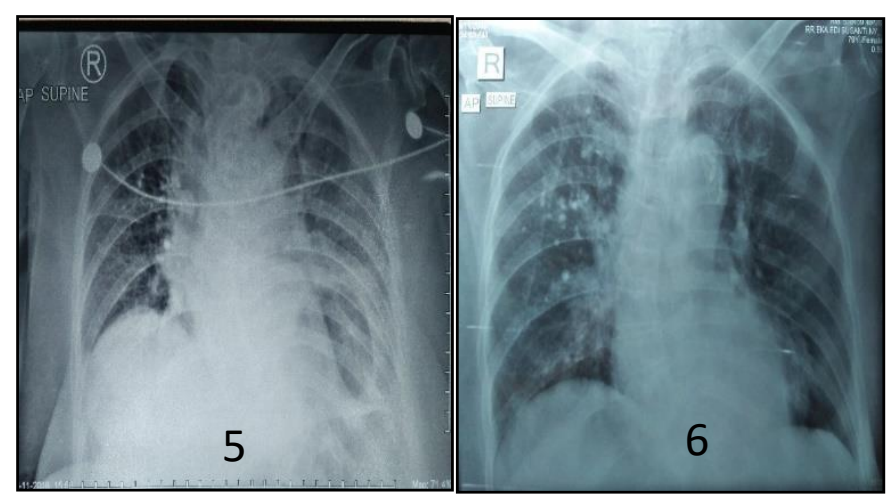

Gambar 5. Menunjukkan foto thoraks saat masuk ICU sebelum dilakukan trakeostomi tidak terdapat gambaran infiltrat. Gambar 6. Foto thoraks hari ke 73 pasca trakeostomi: paru bersih dan tidak terdapat gambaran infiltrate

Tabel 3. Data pasien 3 selama perawatan

\begin{tabular}{cccc}
\hline Kasus 3 & $\begin{array}{c}\text { Hari ke 2 setelah } \\
\text { trakeostomi }\end{array}$ & $\begin{array}{c}\text { Hari ke 14 setelah } \\
\text { trakeostomi }\end{array}$ & $\begin{array}{c}\text { Hari ke 73 setelah } \\
\text { trakeostomi }\end{array}$ \\
\hline Leukosit & 13.640 & 11.710 & \\
Sekret & Tidak purulent & Tidak purulent & Tidak purulent \\
Suhu & $36,5-38,5$ & $36,5-38$ & $36,5-38,5$ \\
\hline
\end{tabular}


Pasien ini dirawat di ICU selama 110 hari kemudian dipindah ke ruangan tanpa terjadi komplikasi pneumonia.

\section{PEMBAHASAN}

Stroke merupakan penyakit dengan angka kecacatan sangat tinggi sehingga memerlukan waktu perawatan dan biaya yang mahal. Selama perawatan di rumah sakit pasien stroke mengalami banyak komplikasi yang memperberat penyakitnya sendiri dan meningkatkan angka kematian. Komplikasi yang sering terjadi pada pasien stroke adalah: ${ }^{6,11}$ (1) infeksi paru/ pneumonia; (2) infeksi saluran urinarius; (3) malnutrisi; (4) dehidrasi.

Diantara semua komplikasi tersebut, maka infeksi merupakan komplikasi paling sering sehingga memperburuk prognosis. Infeksi yang paling banyak terjadi adalah pneumonia (SAP). SAP merupakan infeksi saluran pernapasan bagian bawah yang muncul 7 hari setelah serangan stroke. Angka kejadian SAP sekitar $14 \%$ pada pasien stroke yang dirawat di rumah sakit. ${ }^{6,8}$ Pneumonia merupakan faktor pemicu memburuknya ischemia otak akibat terjadinya secondary insult sehingga kesadaran tambah menurun dan memperburuk prognosis. ${ }^{6}$ Melakukan intervensi secara dini seperti mobilisasi, evaluasi kemampuan menelan, fungsi respirasi, rehabilitasi dini akan dapat mencegah terjadinya komplikasi pada pasien stroke.

Penurunan status mental dan kesadaran sering terjadi pada pasien stroke sehingga memerlukan perawatan di ruang intensif. Perubahan status neurologis pada pasien stroke sering memerlukan observasi yang ketat selama di ICU. Pada pasien dengan GCS di bawah 8 sering terjadi masalah untuk mempertahankan jalan napas tetap aman dan tidak terjadi sumbatan sehingga sering memerlukan intubasi endotracheal dan bantuan napas dengan ventilator dalam waktu yang lama. Pemakaian ventilator yang lama merupakan pencetus terjadinya VAP. Faktor pendukung terjadinya VAP karena oral hygiene yang tidak baik, menumpuknya secret akibat refleks batuk yang tidak adekuat serta gangguan fungsi menelan. ${ }^{6}$

Beberapa penelitian menunjukkan bahwa pneumonia penyebab kematian tertinggi pada pasien stroke. Penyebab pneumonia pada pasien stroke kebanyakan karena aspirasi. Beberapa penelitian menyebutkan aspirasi pada pasien stroke terjadi karena gangguan kemampuan menelan (dysphagia) dan refleks batuk yang tidak adekuat. ${ }^{7}$ Faktor lain yang juga dapat memicu terjadinya aspirasi adalah kurangnya mobilisasi pasien akibat kelumpuhan. Sehingga usaha pencegahan terhadap aspirasi sangat penting dilakukan. Tindakan pencegahan aspirasi dilakukan dengan mobilisasi pasien dan fisioterapi napas berupa tracheal toilet/ bronchial toilet secara rutin. Pada ketiga pasien di atas dilakukan mobilisasi secara rutin dan terjadwal. Suctioning dilakukan untuk membersihkan trakea maupun bronchus dari secret yang tidak bisa dikeluarkan akibat gangguan refleks batuk. ${ }^{6,11}$

Kejadian pneumonia pada pasien stroke dihubungkan dengan penurunan kesadaran dimana secara patofisiologi disebabkan karena: ${ }^{12}$ (1) melemahnya refleks-refleks fisiologis seperti refleks batuk dan fungsi menelan; (2) gagalnya fungsi spincter esophagus bagian bawah; (3) buruknya koordinasi antara menelan dengan bernapas. ada hubungan yang erat terjadinya pneumonia/ sap pada pasien stroke dengan hambatan refleks batuk dan fungsi menelan. akibatnya 
secret akan menumpuk pada saluran pernapasan dan menjadi media untuk tumbuhnya bakteri penyebab pneumonia.

Komplikasi pneumonia akibat aspirasi pada pasien stroke dengan GCS dibawah 8 dapat dicegah dengan menjaga jalan napas tetap aman. Intubasi endotracheal maupun trakeostomi merupakan salah satu tindakan untuk menjaga jalan napas tetap aman. Trakeostomi lebih menguntungkan dibanding intubasi endotracheal. Kekurangan intubasi endotracheal diantaranya: ${ }^{12}$ (1) lebih sulit melakukan suction; (2) kemungkinan terekstubasi sangat besar; (3) terjadi malposisi ETT ke salah satu bronkus yang berakibat one lung ventilation, hypoksia dan collaps satu paru; (4) perlu sedasi yang adekuat; (5) terjadi anatomical dead space lebih besar; (6) sumbatan jalan napas akibat ett tertekuk atau tergigit; (7) melakukan oral hygiene lebih sulit; (8) weaning ventilator lebih sulit dan lama.

Beberapa penelitian menunjukkan bahwa komplikasi pneumonia pada pasien stroke akan memperburuk outcome pasien. Itijika-Jones. et al. menunjukkan ada hubungan antara aspirasi pneumonia dengan beratnya stroke (GCS lebih jelek). Selain itu pada pasien stroke fase akut lebih sering terjadi pneumonia bila tingkat kesadaran dan defisit neurologis lebih berat. ${ }^{6,7}$ Chen et al, Kwan and Hand melaporkan bahwa infeksi post stroke dapat memperpanjang waktu rawat inap di ruang emergency maupun di ICU. Pasien stroke dengan pneumonia rata-rata dirawat 13 hari dibanding tanpa pneumonia yang hanya memerlukan perawatan rata-rata 5 hari. ${ }^{6,11,12}$

Upaya mencegah terjadinya pneumonia hendaknya dilakukan fisioterapi napas, tracheal/bronchial toilet dan suction. Fisioterapi napas, tracheal/bronchial toilet dan suction dapat dilakukan lebih efektif bila pasien sudah dipasang tracheostomi. Trakeostomi dini pada pasien stroke akan mengurangi waktu pemakaian ventilator sehingga dapat memperpendek waktu perawatan di ICU. $4,11-16$

Trakeostomi adalah suatu prosedur yang paling sering dilakukan di ICU. Kira kira $24 \%$ pasien yang dirawat di ICU dilakukan trakeostomi. Indikasi dilakukan trakeostomi di ICU meliputi: ${ }^{13}$ (1) pasien memerlukan ventilator dalam jangka waktu yang lama; (2) gagal melakukan weaning; (3) terjadi sumbatan jalan napas atas; (4) untuk mempertahankan jalan napas tetap aman.

Trakeostomi dapat menjamin jalan napas tetap terjaga aman, memudahkan tracheal/ bronchial toilet, mempercepat weaning, dan dapat mengurangi trauma pada laring akibat pemasangan ETT. ${ }^{14,15}$

Keuntungan trakeostomi dibandingkan dengan intubasi endotracheal adalah: ${ }^{14}$ (1) sedasi dan mobilisasi, trakeostomi akan memberikan rasa nyaman pada pasien karena rangsangan pada laring berkurang sehingga obat sedasi tidak diperlukan lagi, mobilisasi pasien lebih cepat; (2) weaning lebih cepat dan mengurangi waktu penggunaan ventilator. Beberapa penelitian multisenter membuktikan secara signifikan dengan trakeostomi dapat menurunkan waktu penggunaan ventilator; (3) work of breathing, trakeostomi dapat mengurangi tahanan jalan napas sehingga work of breathing berkurang. Dengan menurunnya work of breathing akan mempercepat weaning dari ventilator; (4) mudah membersihkan secret yang dikeluarkan saluran napas (bronchial toilet). Pada pasien dengan 
trakeostomi lebih mudah melakukan suction dan oral hygiene. Dengan trakeostomi juga bisa mengurangi kejadian aspirasi yang sering dihubungkan dengan penyebab terjadinya pneumonia. Intubasi endotracheal erat kaitannya dengan tingginya kejadian infeksi (pneumonia/ VAP) di ICU. Dengan dilakukan trakeostomi akan dapat menurunkan kejadian VAP pada pasien dengan ventilator; (5) kejadian trauma pada rongga mulut maupun laring seperti stenosis laring dan trauma plica vocalis akibat ETT dapat dicegah.

Sejak tahun 1985 mulai dikembangkan PDT. Beberapa penelitian menyebutkan PDT lebih baik dan menguntungkan untuk pasien-pasien kritis yang dirawat di ICU bila dibandingkan dengan surgical tracheostomy. Pada ketiga pasien di atas dilakukan PDT secara dini oleh intensivist di ICU. Beberapa keuntungan PDT dibanding surgical tracheostomi meliputi : ${ }^{16,17}$ (1) luka yang diakibatkan oleh PDT lebih kecil sehingga dapat mengurangi kejadian infeksi; (2) kemungkinan perdarahan lebih sedikit; (3) prosedur lebih cepat; (4) menggunakan obat anestesi lebih kecil sehingga mengurangi efek samping obat; (5) dapat dilakukan di ICU tidak perlu di kamar operasi; (6) komplikasi lebih kecil

Selain punya kelebihan dibanding surgical tracheostomy, PDT juga mempunyai beberapa komplikasi. Komplikasi PDT yang sering terjadi meliputi. ${ }^{10}$ (1) guide wire tertinggal dalam trakea; (2) letak stoma di bagian lateral trakea; (3) trauma pada cincin tulang rawan trakea; (4) trauma pada tulang cricoid; (5) trauma pada dinding trakea bagian belakang; (6) trauma pada oesopagus; (7) false routelcanula trakeostomi di luar trakea; (8) perdarahan; (9) infeksi.
Ketiga pasien stroke di atas dengan GCS di bawah 8 tidak mampu mempertahankan jalan napas tetap aman. Pasien tersebut juga mengalami penurunan refleks batuk dan fungsi menelan yang berpotensi menyebabkan aspirasi. Aspirasi merupakan pemicu terjadinya pneumonia (SAP). Indikasi dilakukan trakeostomi pada pasien tersebut diatas adalah untuk mempertahankan jalan napas tetap aman, mencegah sumbatan jalan napas akibat pangkal lidah jatuh ke oropharing, mencegah terjadinya aspirasi, mempermudah melakukan tracheal/ bronchial toilet dan mempercepat proses weaning. Trakeostomi dilakukan dengan teknik PDT oleh intensivist. PDT merupakan teknik trakeostomi yang menguntungkan karena mempunyai kelebihan diantaranya lebih cepat, tidak perlu transport pasien ke ruang operasi.

Perawatan selanjutnya dilakukan fisioterapi napas, tracheal/bronchial toilet secara rutin sehingga dapat mencegah terjadinya penumpukan secret dari saluran pernapasan. Dari ketiga pasien tersebut tidak ditemukan komplikasi pneumonia. Komplikasi pneumonia dievaluasi dengan pemeriksaan leukosit, evaluasi suhu tubuh pasien, secret dan foto rontgen thoraks.

Trakeostomi dini juga memberikan kemudahan untuk melakukan mobilisasi pasien. Mobilisasi pasien secara berkala juga dapat memperkecil risiko terjadinya pneumonia. Trakeostomi juga memberikan kemudahan dalam melakukan perawatan pada pasien tidak sadar di ICU. Dengan dilakukan trakeostomi dapat melakukan oral hygiene, mobilisasi, bronchial/ tracheal toilet lebih mudah. 
Perawatan ketiga pasien di atas memerlukan waktu yang lama. Hal tersebut berbeda dengan temuan Chen $e t$ al. Kwan and Hand yang melaporkan bahwa pasien stroke dengan pneumonia rata-rata dirawat 13 hari dibanding tanpa pneumonia yang hanya memerlukan perawatan rata-rata 5 hari. ${ }^{6,11,12}$ Perbedaan tersebut terjadi tidak terlepas dari kondisi pasien saat masuk ICU dengan GCS di bawah 8, diperberat dengan usia lanjut (geriatric) sehingga memerlukan perawatan lebih lama.

Tentunya diperlukan penelitian dengan sampel yang lebih besar untuk menunjang bahwa trakeostomi dini merupakan upaya untuk mencegah terjadinya pneumonia dan memberikan kemudahan dalam perawatan pasien stroke di ICU seperti yang dilaporkan pada laporan kasus ini.

\section{KESIMPULAN}

Pasien stroke dengan GCS dibawah 8 akan mengalami perawatan yang lama dan potensial terjadi komplikasi berupa SAP maupun VAP bila memakai ventilator. Trakeostomi dini selain memberi kemudahan dalam perawatan, kemudahan melakukan tracheal/ bronchial toilet, oral hygiene, mobilisasi pasien dan mempercepat weaning juga merupakan upaya untuk mencegah terjadinya pneumonia. Teknik trakeostomi dengan PDT mempunyai keuntungan bila dilakukan pada pasien kritis.

\section{DAFTAR PUSTAKA}

1. Sims NR, Muyderman H (September 2009). Mitochondria, oxidative metabolism and cell death in stroke. Biochimica et Biophysica Acta. 2009. Pp 80-91.

2. Prathivi N. Detecting and dealing with strokes. Nama Jurnal. July 1, 2014
3. Langhorne P, Stott DJ, Robertson L, MacDonald J, Jones L, McAlpine C, Dick F, Taylor GS, Murray G.P. A complications after stroke: a multicenter study. Glasgow: 2000. VOL 31:pp 1223-9.

4. Finlayson O, Kapral M, Hall R., et al. Risk factors, inpatient care, and outcomes of pneumonia after ischemic stroke. Neurology. 2011; Vol 77: pp 1338

5. Bösel1 J, Schiller P, Hacke W, and Steine T. Benefits of early tracheostomy in ventilated stroke patients? Current evidence and study protocol of the randomized pilot trial SETPOINT (Strokerelated Early Tracheostomy vs. Prolonged Orotracheal Intubation in Neurocritical care Trial). Heidelberg: International Journal of Stroke; 2012; Vol 7:173-182

6. Eltringham SA, Karen Kilner, Gee M, Karen Sage, Benjamin D. Bray, Pownall S, Smith CJ., Impact of Dysphagia Assessment and Management on Risk of StrokeAssociated pneumonia: A Systematic Review. Manchester: Cerebrovascular Disease. 2018; Vol 46: 97-105

7. Cabrini L1, Monti G, Landoni G, Biondi-Zoccai G, Boroli F, Mamo $\mathrm{D}$, et al. Percutaneous tracheostomy, a systematic review. Acta Anaesthesiol Scand. 2012; 56(3):270-81

8. Karvandian K, Mahmoodpoor A, Beigmohammadi M, Sanaie S. Complications and safety of percutaneous Dilatational tracheostomy with griggs Method versus surgical tracheostomy: $A$ prospective trial with six months follow-up. Pak J Med Sci 2009;25(1):41-45

9. Gilbey P. Fatal complications of percutaneous dilatational 
tracheostomy. Bar Ilan University. American Journal of OtolaryngologyHead and Neck Medicine and Surgery. 2012; Vol 33: 770-773

10. Dulguerov, Pavel, et al. Percutaneous or Surgical Tracheostomy: A Meta-Analysis. Critical Care Medicine. 1999; Vol. 27, No. 8: 1617-25

11. Sara R. M, Almeida1, Mariana M, Bahia1, Fabrício O. Lima1,et al. Predictors of pneumonia in acute stroke in patients in an emergency unit. Campinas: Arq Neuropsiquiatr. 2015; Vol 73:415-419

12. Ifejika-Jones NL, Harun $\mathrm{N}$, Peng $\mathrm{H}$, Noser EA, Grotta JC, Francisco GE. The Interaction of Aspiration Pneumonia with Demographic and Cerebrovascular Disease Risk Factors is Predictive of Discharge Level of Care in the Acute Stroke Patient. Lippincott Williams \& Wilkins: American Journal of Physical Medicine \& Rehabilitation. 2012; 91:141-147

13. Sui1 R, Zhang2 L. Risk factors of stroke-associated pneumonia in
Chinese patients. Jinzhou: NeurologicalResearch.2011; Vol 33:508-513

14. Longworth A, Veitch D, Tracheostomy in special groups of critically ill patients: Who, when, and where? Indian Journal of Critical Care Medicine. 2016; Vol 20: 253-337

15. El-Anwar MW, Abdel-Fattah A, Nofal and Khazbak AO. Tracheostomy in the Intensive Care Unit: a University Hospital in a Developing Country Study. RiodeJaneiro: International Archives of Otorhinolaryngology. 2017; Vol. 21: 33-37

16. Muralidhar K. Bangalore. Tracheostomy In ICU: An Insight into the Present Concepts. Indian Journal of Anaesthesi. 2008; Vol 52:28-37

17. Youssef TF, Ahmed RF, Saber A, Percutaneous dilatational versus conventional surgical tracheostomy in intensive care patients. North American Journal of Medical Sciences. 2011; 3: 508-512 